\title{
The Maritime Rise of China in Indo-Pacific and Indo-US Counter Balancing Approach
}

\author{
Huma Amin ${ }^{1, ~ *, ~ A r s l a n ~ R a f i q u e ~}{ }^{2}$ \\ ${ }^{1}$ School of International and Public Affairs, Jilin University, Changchun, China \\ ${ }^{2}$ Department of Politics and International Relations, University of Sargodha, Sargodha, Pakistan
}

Email address:

Humaamin69@yahoo.com (H. Amin)

*Corresponding author

\section{To cite this article:}

Huma Amin, Arslan Rafique. The Maritime Rise of China in Indo-Pacific and Indo-US Counter Balancing Approach. Journal of Political Science and International Relations. Vol. 4, No. 1, 2021, pp. 18-23. doi: 10.11648/j.jpsir.20210401.13

Received: February 8, 2021; Accepted: February 23, 2021; Published: March 17, 2021

\begin{abstract}
The study of international relations evolve around the study of the power relation between significant states. Powerful nations have funded divergent views to develop political values and ideologies. The global system has been dominated since the Cold War by the United States (US), which has been shaken by the relative decline of the US economy and China's simultaneous rise. China is rapidly emerging, assuming that the Indo-Pacific region is a serious challenger to IndoUS interests. Because their strategic responses are growing against each other, the states are adopting hedging policies. Simultaneously, the outbreak of coronavirus disease (COVID-19) affects the balance and order of power. In the throes of stiff US-China competition, a crumbling European project, de-globalization and a contested economic development landscape, the pandemic came. Although the American leadership role was aggravated by this pandemic, Beijing, on the other hand, has also distanced itself from the existing global order. The clash of rhetoric, narratives, and perceptions has been sharpened. As a serious challenger to the interests of Washington in the globalised world, China is rapidly rising specifically in Indo-Pacific region. Unlike the Cold War era, among the states of the world, the intense balance of power politics in the form of alliances is present. The hedging strategies are still being adopted by the states to counter the existential threats of hard balancing and soft balancing.
\end{abstract}

Keywords: Indo-Pacific, Maritime Rise, Counterbalancing, United States Approach, Peaceful Coexistence, Rise of China

\section{Introduction}

Global politics is in transition. Before the coronavirus, the geopolitical trends have escalated, and US-China competition became more pronounced throughout the globe. The critical struggle plays out in the newly emerging Indo-Pacific region due to the internal and external actors. Moreover, theIndoPacific geographical concept hasbeen replaced by the obsolete Asia-Pacific vision that appeared in past political thinkers and politicians' writings and speeches from time to time. The Indo-Pacific region refers to the confluence of the interconnected Pacific and Indian Oceans of Southeast Asia. On the other hand, Beijing confronts the Indo-Pacific paradigm as it sees it as the result of American attempts to increase economic and military capabilities. Many believe this new model's rise is only a matter of cold-blooded, Cold
War-style strategic thinking.

Moreover, China's geography still elevates it to seek an outlet to the Indian Ocean to pursue economic and military expansion. Southeast Asia and the Indian Ocean are the only natural highways for China's development, with mountains, steppes, and deserts to the west and northwest. It is the case in Marco Polo's day, and it is still so. Another illustration demonstrating this premise was the Chinese sailor Zheng He, who traveled to the Indian Ocean in the early fifteenth century to create a long-term Chinese presence there. The Indian and Pacific Oceans are very intertwined in this way [3]. Japan's expansion during WWII exposed a military path toward Southeast Asia and deeper into the Indian Ocean. Aside from historical and geographical context, the emergence of the Indo-Pacific definition and re-emergence is accompanied by closer relations between India and Japan. Both nations are China's neighbors and seem worried about 
the far-reaching impact of China in the region. They also see the need to work together on military and economic problems and attract Australia and seek greater US support. A sort of quadrilateral format is emerging in the form of treaties and dialogues that appear as the new version of a long-term strategy explicitly towards China.

China overtook Japan in 2010 to become the secondlargest economy in the world. China has shown increasing effects in several ways as the largest socialist country. In many ways, China has demonstrated a growing impact. Ideological inequalities and China's economic success make Western countries like the EU and the US full of concerns about China's development to varying degrees and at different levels [1]. The Obama administration introduced the 'Asia-Pacific Rebalance' or 'Return to Asia-Pacific' strategy at the 19th APEC summit in 2011, suggesting a subtle US trend. China overtook Japan in 2010 to become the second largest economy in the world. But China was still on the path of being an important force at that time, rather than a true one. Therefore, the US has adopted anti-China hedging strategies, using cooperation and competition as two policy tools for dealing with China [2]. However, with the coming to power of the Trump administration and the further intensification of the United States' systemic pressure, these two countries have gradually turned to a situation of complete rivalry, as one of the traditional manifestations is the Sino-US trade war. The 'Indo-Pacific strategy' is the central strategic embodiment of their full competition.

China's rising and growing maritime presence in the IndoPacific region has led to a strategic convergence between India and the US, and the most recent clashes between Chinese and Indian forces in the Galwan valley have also contributed to this Indo-US partnership. Under India's major political parties' administrations, the Indian government's official stance on China has always been subdued and complex. Apparently, both India and the United States, albeit to varying degrees, have relations with China with elements of cooperation, competition, and possibly conflict. Each nation has a mixed approach to engaging China, despite planning for a turn for the worse in Chinese conduct. Each sees a place for the other in his strategy for China. Each believes that China receives a signal from a good relationship with the other, but neither of them wants to provoke or force Beijing to choose one of them. Each also acknowledges Beijing that drives the Indo-US partnership. There were arguably three imperatives in the United States for a more robust relationship with India and to support its rise such as strategic interest, especially in the context of China's rise, economic interests, and shared democratic values. Both the US and India are strengthening its strategic convergence likewisein his distinctive style PM Modi hosted the US. President Donald Trump in the city of Gujarat regaled him on February 24 of this year at a rousing road show from the airport to Motera Stadium, believed to be the largest cricket stadium in the world. During the visit, it was proclaimed to have been elevated to a "Global Comprehensive Strategic Partnership," and PM Modi lauded it as one of the defining partnerships of the 21 st century. China was clearly the elephant in the room for this meeting, as revealed when President Trump compared India's democracy to an unnamed "nation that seeks power through coercion, intimidation and aggression [4]." Moreover, this study's central focus is to highlight the rise of China through the theoretical approach of realism and counter balancing approach by US and India in Indo-Pacific region. This paper will highlight the threat perceptions perceived by the US and India from China's maritime rise and how these powers will cope these threats through the balancing approaches in the region.

\section{Theoretical Approach}

There are several literatures about the variables that influence state actions in international relations. The state is logical in conventional cognition, and its function is to preserve and expand control. Realists think force decides the needs of the states. The will to power of humans also has a major impact on that [5]. However, structural realists assume that the structure was the determining factor attempting to control the state's actions. The variation in structure lies not in the difference in the unit's characteristics or functions, but in the difference in unit capacity. Neo-classical realism, such as the system factor, state factor and individual factor, combines many variables together. This theoretical model analyzes more accurately and comprehensively the variables that influence state behaviors. It demonstrates that numerous and complex processes are state behavior and state decisionmaking. This is the product of the structure's elements and a thorough reflection of countless variables within the region. The mechanisms of cognition, decision-making and policy formulation, while addressing similar international problems, will concentrate on different countries and their behavioral responses will be very different [6]. But signals from the international community to the country are not always so easy to recognize, and leaders may not accurately monitor them. It is more difficult for them to make rational and empirical decisions all the time. National capacity is another aspect that needs to be addressed, in addition to that. Thus, "recovering the state" is essential.

Furthermore, when the structure or structural pressure of a country changes the nature of the international system, the country can first consider its own global strategy, particularly for superpowers. In addition, in its strategic adjustment [7], the unique domestic strain that the country currently faces is also an important factor. It is relatively time-sensitive and is also an efficient way for politicians to collect political capital. The style of leaders is also a key factor when evaluating state actions. People have used this factor in the past to evaluate autocratic countries, as the impact of leaders on policy behavior is more important for such nations in the decision-making process. Actually, however, the same is true of democratic countries, where presidential states give presidents many major powers. In national policy, whether in the negotiation phase or the decision-making process, leaders' personal style plays an important role. Massive, 
small and medium-sized forces may have different influences as the strain of the system changes. When leaders respond positively to challenges, rivalry in their national strategy will increase in the face of rising forces, and the role of the state in the international community is the most important component of domestic variables. The international position influences a country's strategic pattern greatly. Because of its different position in the international community, a country's foreign policy can be different. Even though elections almost never determine foreign policy issues in democratic countries, foreign policy is still an important topic. For example, the election of Trump was carried out under the motto of "Making America Great Again."

As China's economic strength increases and its incorporation into the global governance system continues to accelerate, China's regional and global impact is growing. The world's only hegemonic nation, the United States will feel immense systemic pressure from any possibility that might jeopardize its ranking. At the same time, at the national level, the United States has always had the sense of dominance of "Manifest Destiny" and "America first" and it will never allow other nations to exceed it, i.e. the "hegemonic mentality" in the United States' global strategy. Besides, Trump's practical thinking has deeply changed American strategy [8]. In addition, Trump's practical thinking has deeply changed American strategy. In the face of increasingly fierce competition between China and the United States, a trade war broke out between them. It reflected not only in economics, but also in agriculture, science and technology, humanities and other fields. And in terms of global policy, Trump introduced the 'Indo-Pacific Strategy' to strengthen the US presence in the Asia-Pacific region and to expand into the Indian Ocean region.

\section{Rise of China and Concept of Balancing}

Balancing is one of the most used words in the realist tradition. Walt describes "allying with others against the prevailing threat" as balance. Instead of bandwagoning (aligning with the source of danger) states "join alliances to protect themselves from states or coalitions whose superior resources pose a threat." Walt also acknowledges four sources of threat, such as Aggregate Strength, Geographic Proximity, Offensive Power, and Aggressive Goal. As far as aggregate power is involved, and it is challenging to calculate. Nonetheless, issues such as population, economy, land, industrial and military capabilities, as well as technological levels, all converge globally on the sustainability of a given country's influence. Moreover, this rising power can be easily turned into a perceived threat by its neighbors or even rivals from afar. Because the ability to project power decreases with geographical proximity to distances is an important issue. Therefore, perceived threats from a neighboring state are generally taken more seriously than from a distant one. Regional states, in fact, are more vulnerable to threats from other regional powers. Typically, if the threatening state is too close and heavy for a quick victory, a balancing tactic or a bandwagoning alternative is activated by the threats [9]. Aggressive intentions are the final type of danger and, in certain situations, are determined to create a balancing mechanism; it is not a safe option for the poorest states to bandwagon with highly aggressive states many times. Therefore, Walt concludes that the threat balance system (where threat imbalances create alliances against the most dangerous state) subsumes the power balance theory (where power imbalances create alliances against the strongest state), "since aggregate power is an important component of threat, but not the only one."

National states are actively involved in balancing actions: trying to weigh interests and values; guns and butter; economic benefits and national security. However, one balancing act today supersedes all others: balancing in reaction to the rise of China. Balance is one of the oldest and most intuitive principles of the theory of international relations. The prominent realist school advises that a nation's rapid acquisition of power has traditionally proven to be destructive, providing neighbors and peers with an unpalatable choice: bandwagon with the imminent risk by aligning with it or balancing their defenses against attack or coercion. Most of China's neighbors and peers are struggling to remain as diplomatically and economically as possible engaged with the rising Asian power while taking the minimum steps necessary to preserve their security and sovereignty [10]. Many, including the Association of Southeast Asian Nations (ASEAN) member states, have shown aversion to more advanced, powerful balancing initiatives such as treaty alliances, multilateral military exercises, and joint navigational freedom and naval patrol operations. None, including the "Quad," a group of IndoPacific democracies consisting of Australia, India, Japan, and the United States, have seriously embraced a Cold War-style containment strategy.

\section{Indo-US Threats Perceptions Towards China}

During the past few decades, China has undergone an unparalleled economic boom. After mid-2000, China's nominal GDP has skyrocketed to become the world's second largest after its steady rise of 16 and beat Japan in 2010. The US remains in its place as the largest holder of GDP, gradually rising its nominal GDP, but China is projected to surpass it in the next few decades. In terms of the pace of economic growth, China's real GDP growth has slowed in recent years, dropping from a high of $14.2 \%$ in 2007 to $6.3 \%$ in 2019 [11]. However, along with India, China remains relatively high in its rate of growth compared to the other Quad countries, which have seen their economic growth slower. Economic development in China has brought immense benefits to many countries worldwide, and the Quad countries are no exception. As of 2017, the share of 17 
merchandise imports from China was the highest in all four nations, accounting for $24.5 \%$ in Japan, $21.9 \%$ in Australia, $21.8 \%$ in the US and $16.6 \%$ in India [12].

Moreover, the Australia and India are reluctant to deepen security cooperation in a quadrilateral sense due to their economic relations with China despite the willingness of Japan and the United States, whose trade amounts with China are even higher than Australia and India, is invalidated by the evidence that all Quad countries depend on China in their trades. Recently, China has also steadily increased its military spending and succeeded in modernizing its military capabilities. There was a substantial increase in China's overall military spending from around 41 billion US dollars in 2000 to 228 billion US dollars [13]. China's military budget outnumbered that of the three countries except the US as of 2001 compared to the Quad countries and continued to expand the gap while the other three countries did not see drastic shifts in their military spending, if anything, they saw a slight rise. While the US has remained in its role as a military hegemon, China is gradually closing the gap with the US in its military strength, year after year by far the largest military spending. In recent years, there has been a growing use of "assertiveness" to describe China's activities in the region in political, media and even academic discourse. This could indicate that China has steadily demonstrated its hostile ambitions in the region. One of the main examples of this assertiveness, in which several nations, including China, Taiwan, Vietnam, the Philippines, Malaysia and Brunei, claim territorial rights, is the Chinese land reclamation activity in the Spratly Islands in the South China Seas. China unilaterally initiated its reclamation projects at several locations on the Spratly Islands in order to assert its territorial claims in the region [14]. This series of unilateral actions by China contributed to the escalation of tension in the area as the building of military facilities such as radar dorms, runways and ports was observed along with land reclamation. China has so far carried out its reclamation operations in a total of seven locations on the Spratly Islands. The unilateral Air Defense Identification Zone (ADIZ) declaration in the East China Seas is another example. ADIZ is identified as a specified area of airspace within which, in the interest of national security, the ready identification and control of aircraft is required and usually has no legal binding force. In the East China Seas, China unilaterally declared its establishment of the new ADIZ. Since the specified area consists of the disputed Japan-controlled Senkaku Islands and, to some extent, overlaps with the ADIZ of South Korea and Taiwan, the lack of mutual understanding and hence the instability of the region gives rise to potential conflicts. Given China's increasing military and economic power over the US, Japan, Australia and India and its actions in the area that seem hostile, it has thus sparked great concern and criticism from neighboring countries as well as many EU countries and the US.

\section{Indo-US Internal Balancing Approach in Indo-Pacific}

The regional dynamics of the Indo-Pacific are changing. The United States' unipolarity is weakening as China's emergence as a powerful naval force is growing. With Beijing's anti-access capabilities in today's world, China may also be able to block the U.S. navy's advance to its shores during a maritime crisis. At about the same time, the US and Asia allies are apprehensive about the country's leadership in the region, the first strategy of President Trump in America. The Indo-Pacific region countries must turn to regional balancing mechanisms, such as the Quad, with a view to increasing Chinese domination and the uncompromising United States, to jointly contain Beijing and prevent the growth of Chinese regional and global hegemony. Without formally forming an open military alliance, the Quad's formation will enable like-minded nations in the Indo-Pacific to combat China. India, Japan, Australia, and the United States will be encouraged to use a soft balancing strategy against China's hegemony, with four countries with distinct geopolitical objectives, security priorities, and alliance views. In this regard, the Quad will be based primarily on internal balancing, allowing each nation to emerge in its respective Asian corners as a strong regional power such as Japan in the Asian corner.

In recent decades, in the Indo-Pacific hemisphere, India, Japan, and Australia have doubled their conventional forces to defend their interests. While its constitution has historically banned Japan from spending more than one percent of its gross domestic product (GDP) on defense, Tokyo is acquiring advanced defense systems and gradually shedding its security policy's pacifist aspect. Japan recently decided to purchase Lockheed Martin's 42 F-35 joint strike fighters and commissioned JS Kaga, an indigenous 24,000ton helicopter carrier. Japan could independently protect its interests in the East China Sea dispute with China, with a strong naval force. As an emerging economic giant and military force, India is slated to play a crucial role in defending the Indian Ocean. According to a Stockholm International Peace Research Center study, India estimates that $\$ 55.9$ billion was invested in 2016 as the world's fifth largest military spender [15]. With its ongoing naval buildup, India is trying to become a preeminent force in the Indian Ocean Region (IOR), primarily to counter China's naval expansion into the Indian Ocean. It has set an objective to maintain a fleet of 212 warships and 458 aircraft by 2027, up from the Indian Navy's current 138-warship and 235-aircraft force.

The Indian Fleet's most notable Naval Strategic Plan emphasised New Delhi's focus on maritime security problems arising within the IOR. Analysts commented on the apparent shift in Delhi's strategic approach to IOR, including its newly discovered willingness to become an Indian Ocean net security provider, following this strategy's publication in 2015. By establishing a strategy to deploy mission-ready ships and aircraft across the Indian Ocean along vital 
maritime communication lines, India adopted this concept in 2017. (SLOCS). In recent years, the navy allegedly implemented this strategy to combat China's practice sending submarines and warships into the IOR. Thus, this naval expansion indicates New Delhi's increasing assertiveness in containing China in the Indian Ocean. While Australia has traditionally not expressed the same concerns about the challenge posed by China's rise as Japan and India, in recent years, Australia appears to be less sensitive to China's uproar. It may be able to become an assertive maritime power in the Indian Ocean and the South Pacific. It took steps to revitalize its navy and signed an agreement in 2016 with DCNS of France to procure $\$ 41$ billion worth of 12 conventional submarines [16]. Although Canberra is less involved than Tokyo and New Delhi, to protect its interests in the region, Canberra is strengthening its security alliances with Japan, India and other major Asian countries. Furthermore, its close diplomatic ties with the ASEAN countries would help curb China's economic power in Southeast Asia. The United States, the fourth member of the Quad, will continue to be the dominant naval power in the Indo-Pacific region. US Secretary of Defense Jim Mattis recently announced that China's high-power competition would be the United States' biggest challenge. Given this argument, the United States is likely to concentrate on militarily countering China's active defense stance, providing Japan and India with defense systems and technology, and promoting joint naval drills, such as the Malabar trilateral naval exercises. Diplomatic outreach from the United States can also go a long way in uniting Japan, India, and Australia, three countries which have not always seen Chinese rise in the past.

The formation of an associated quadrilateral grouping may also help combat China's rise globally. In Africa, India and Japan are now taking the initiative to combat the China Belt and Road Initiative (BRI). The two countries are focusing on building industrial corridors and networks between Asia and Africa through the India-Japan Dialog on Africa. They proposed developing an Asia-Africa Growth Corridor (AAGC), to which Tokyo has pledged \$200 billion. The AAGC's focus is to guarantee that African nations in most need of revenue stream do not succumb to the economic necessity of China's accession to the BRI and to counter China's increasing impact on Africa through the construction of infrastructure facilities, particularly in coastal countries.

\section{Conclusion}

In the 21 st century, the Indo-Pacific has become a locus of emphasis. It brings together large sections of the globe, which has made it a major geopolitical force. The nearly simultaneous rise of China and India and the rapidly changing region dynamics are now making this construct even more important. China's growing military presence, growth, and the US, Australia, India, and Japan's push-back add to that prominence. Others perceive it as a potentially destabilizing power as China's strength grows. it raises the stakes of strategic competition and increases the potential for conflict, particularly in the Indo-Pacific maritime domain. This study highlights the real differences between China's interests and other Indo-Pacific powers and the differences between China's strategic maritime objectives. Regional powers are strengthening their maritime military capabilities due to their perceptions of Chinese ambitions and are intensifying their security links with the United States and with each other. In addition, in the triangular relationship between India, China, and the United States, the coronavirus pandemic has resonated, further exacerbating Sino-Indian tensions that have already been growing for several years. COVID-19 would certainly impact geopolitics between countries in Asia, and the triangular ties between the United States, China and India would be reshaped and redefined. Besides, in this shifting equation, the India-US strategic partnership is likely to be further strengthened, with both countries watching over China's increasingly belligerent role in the Indo-Pacific region.

\section{References}

[1] Amorim, W. (2014). Japan and India: soft balancing as a reaction to China's rise? Revista Brasileira de Politica Internacional.

[2] Bader, J. A. (2013). Obama and China's Rise An Insider's Account of America's Asia Strategy. New York: Brookings.

[3] Beech, H. (2018, September 20). China's Sea Control Is a Done Deal, 'Short of War With the US'. New York Times.

[4] Choudhury, A. (2018). Strategic-Maritime Triangle in the Indian Ocean: An Emerging Indo-US Naval Entente? $A$ Journal of International Affairs.

[5] Company, M. a. (2017). China's Role in the Next Phase of Globalization. Washington DC: Mckinsey Global Institute.

[6] Das, R. N. (2020). The India-U.S. Defense Relationship Grows Amid Rising Tensions with China. Global Research and Analysis.

[7] Haass, R. (2020, april 7). The Pandemic Will Accelerate History Rather Than Reshape It. Foreign Affairs.

[8] Medeiros, E. S. (2010). Strategic hedging and the future of Asia - pacific stability. The Washington Quarterly.

[9] Morgenthau, H. J. (1989). Politics Among Nations: The Struggle for Power. London: Methuen Publishing.

[10] Paul, J. M. (2018, Jnauary 18). THE QUAD: A SOFT BALANCING MECHANISM IN ASIA. South Asian Voices.

[11] Scott, D. (2019). China's Indo-Pacific Strategy. Journal of Territorial and Maritime Studies.

[12] SMITH, J. M. (2019). CHINA'S RISE AND (UNDER?) BALANCING IN THE INDO-PACIFIC: PUTTING REALIST THEORY TO THE TEST. Texas National Security Review.

[13] Waltz, K. N. (1979). The Theory of International Politics. McGraw-Hill. 
[14] Waltz, K. N. (2001). Man, the state, and war: A theoretical analysis. Columbia University Press.

[15] Xinhuanet (2018). China plans to impose a 25\% tariff on 14 categories of 106 items such as soybeans, automobiles and chemicals of the United States. Retrieved from http://www.xinhuanet.com/fortune/2018-

04/04/c_1122639386.htm (accessed on 15 April 2018).
[16] Pompeo, M. (2019) The 52nd Anniversary of the Founding of the Association of Southeast Asian Nations, SECRETARY OF STATE, 2019.8. Retrieved from https://asean.usmission.gov/the-52nd-anniversary-of-thefounding-of-the-association-of-southeast-asian-nations/ (accessed on 15 November 2019). 